DE DE GRUYTER OPEN

\section{Research Article}

(c) 2018 Angkasah et.al. This is an open access article licensed under the Creative Commons Attribution-NonCommercial-NoDerivs License (http://creativecommons.org/licenses/by-nc-nd/3.0/).

\title{
Bureaucratic Reform in the Perspective of State Administration Law
}

\author{
Lalu Angkasah ${ }^{1}$ \\ Huala Adolf ${ }^{2}$ \\ Gatot Dwi Hendro Wibowo ${ }^{3}$ \\ Zainal Asikin ${ }^{3}$ \\ ${ }^{1}$ Student of Doctoral Law Study Program, Postgraduate Program, \\ Mataram University, Indonesia \\ ${ }^{2}$ Professors and Lecture of Law Faculty University of \\ Padjadjaran, Bandung, Indonesia \\ ${ }^{3}$ Professors and Lecture of Law Faculty, \\ Mataram University, Indonesia
}

Doi: $10.2478 / \mathrm{mjss}-2018-0094$

\section{Abstract}

This study aims to (1) analyze the development of bureaucratic reform regulation in Indonesia; (2) analyze the aspects of State Administration Law within the Government Bureaucracy; (3) examine obstacles in the implementation of bureaucratic reform in Indonesia; and (4) find bureaucratic reform model in Indonesia in the future. The ideal model of bureaucratic reform in Indonesia in the future can only be realized by improving the quality of the implementation of responsive and pro-service public services. For that reason, it takes the role of government bureaucracy in improving the quality of service through various innovative policy strategies by utilizing the application of various systems of information technology and administration.

Keywords: bureaucratic reform, bureaucratic reform model, state administration law

\section{Introduction}

Civil Servants serve to provide services to the public. Their performance always becomes the object of supervision and examination. Therefore, in carrying out tasks and functions, they must refer to the prevailing laws and regulations as well as the general principles of good governance to ensure good and clean governance from corruption, collusion and nepotism practices in Indonesia in accordance with the agenda of bureaucratic reform.

The focuses of the study are:

a. What is the philosophical, juridical, theoretical and sociological foundation of bureaucratic reform in the perspective of State Administration Law?

b. How is Bureaucratic Reform in the perspective of State Administration Law implemented in Indonesia?

The objectives in the study are:

a. To understand the problems of bureaucratic reform in the perspective of State Administration Law seen from the philosophical, juridical, theoretical and sociological aspects in the reform era of Indonesia

b. To examine bureaucratic reforms in the perspective of State Administration Law 
This study is categorized as normative legal research. It examines and analyzes the legislation, legal principles and legal norms with a view to obtain a clear picture of bureaucratic reform seen from State Administration Law (Soemitro, 1999). The approaches used in the study are:

a. Statute approach that is an approach done by reviewing legislation and regulations relating to legal issues being addressed (Ibrahim, 2005). The statute approach used in the study relates to the rules and laws governing bureaucratic reform under the Law State Administration;

b. Philosophical approach that is an approach to describe the rational background of the formation and development of a legal system that ever applies. This study focused on the development of bureaucratic reform on civil servants in terms of laws of the State Administration that determines the law;

c. Conceptual approach that is an approach which evolves from the views and doctrines that develop in the legal science (Marzuki, 2006);

d. Comparative approach which is, in this study, serves as supporting science for legal dogmatic. In other words, it considers certain arrangements and settlements of another legal order and judge.

Management and analysis of collected legal materials was done through juridical qualitative method guided by several principles. First, it must be based on the hierarchy of legislation (compliance with the principle/consistent). Second, the existing legislation should not conflict each other. Third, there is legal certainty as the order for the arrangement of relations between the right men for the implementation of justice (Ardhiwisastra, 2000).

The steps taken were observing all the results obtained from the legal materials followed by preparing the concepts, principles and legal provisions related to bureaucratic reform arrangement in the perspective of State Administration Law. Furthermore, each variable was linked by using deductive reasoning to produce concepts, definitions, descriptions and classifications as the result of the study. The last step is interpreting the legislation and law using:

a. Principal interpretation, a method of interpretation that aims to understand the law by seeking the conformity of existing legal principles. This interpretation is based on the principles that become the basic reference and at the same time explores new principles in connection with the analysis of bureaucracy norms, theories and practices of reform in the State Administration Law;

b. Historical interpretation, a method of understanding law in a historical perspective. Historical interpretation is made to the norms, theories and practices of bureaucratic reform in terms of the Laws of State Administration, by relating them to history. This is important to be carried out in order to better understand the background and purpose as well as psychological atmosphere at the time of formation of aspects that become the foundation of philosophical, juridical, theoretical and sociological reform of bureaucracy viewed from the State Administration Law;

c. Systematic interpretation, a legal method of law in relation to the prevailing law (Indonesian positive law) with the steps of exploring bureaucratic principles and theories of reform in review of the Laws of State Administration. It aims to identify, classify and compare to find out the characteristics of each (Suwoto, 1990).

\section{Research Methods}

This study is a normative legal study, which is based on norms, values, legal principles, legal concepts, legal opinions and research results. Therefore, the methods used involve:

\subsection{Approaches}

The approaches implemented in the study are normative approach which includes statute approach, conceptual approach and analytical approach. 


\subsection{Source of legal material}

The legal materials were obtained through library research which consists of primary legal materials in the form of Laws, Government Regulations, Presidential Regulations, Regional Regulations, and others; secondary legal materials in the form of concepts, expert opinions, and research results; and tertiary legal materials in the form of language dictionaries and legal dictionaries (Soekanto, 1984).

\subsection{Legal material collection technique}

The collection of legal materials were conducted by reviewing and analyzing the literature materials, that is examining the laws and regulations as well as books, and the results of prior research related to this legal issue.

\subsection{Methods of analyzing legal material}

The method used is descriptive normative, that is the analysis of legal materials by making legal interpretations, either authentic interpretation, grammatical interpretation or systematic interpretation.

\section{Discussion}

\subsection{Bureaucratic Reform in Indonesia: Constraints and Challenges toward Change}

Bureaucracy reform is wanted by various parties, but it is quite challenging to realize. There are enough theories about bureaucracy improvement for better governance; however the implementation requires hard work and strong commitment from all related parties, not only the bureaucrats but also the people (KPK, 2008).

In Indonesia, bureaucratic reform still remains a dream; although in the last 10 years, there have been efforts to improve government bureaucracy. The development of bureaucratic reform in Indonesia is not as fast as what people imagine. Not only Indonesia, but also various countries, such as China, Japan and South Korea, has shown that there is no instant result in bureaucratic reform (Prasojo, 2008). A strong commitment and consistency in the implementation of bureaucracy are highly required. Related to 'slowness' implementation of bureaucratic reform in Indonesia, there are several factors that still become obstacles and challenges which will be elaborated below.

\subsection{The Lack of Commitment and Political Leadership}

This element is the determining factor that becomes obstacles in the implementation of bureaucratic reform. The strong commitment and political leadership to change the bureaucratic paradigm will determine the success of this bureaucratic reform. There are many examples in countries, such as China, Japan and South Korea, that the leaders are strongly committed to implement bureaucratic reform so that the objectives can be achieved (Brodjonegoro, 2008). The essence of political commitment and leadership in bureaucratic reform should not merely become a discourse. It must be realized. This includes a clear roadmap on the agenda of bureaucratic reform setting. In short, the stronger the commitment and political leadership to reform the bureaucracy is, the greater the chances of success are.

\subsection{Bureaucratic Politicization}

Politicization of bureaucracy in Indonesia is not only happening at this time, but has happened since Indonesia under the Dutch East Indies government. Cooptation of political parties or other interests against bureaucracy has become an acute thing. This makes the bureaucracy weak and does not fully take sides with the public interest. It is still happening and hinders bureaucratic reform 
that should have changed for the better. If the bureaucracy is not coopted for the political interests of a particular group, the acceleration of bureaucratic reform will be better.

\subsection{Opposition (resistance) within the Bureaucracy}

This point is the obstacle as well as challenge in the implementation of bureaucratic reform. The "comfortable zone" felt by the bureaucrats (status quo) makes them difficult to change their mindset and mental attitude to support a better change. Internal opposition (bureaucrats) occurs to change efforts which become the core of bureaucratic reform. The unwillingness to change the mindset including the work culture of the existing bureaucrats is certainly a constraint in the change. Therefore, this is a crucial factor in the implementation of bureaucratic reform in Indonesia.

\subsection{The Lack of Competence in the Implementation of Bureaucratic Reform}

Bureaucracy reform will not succeed if there are no human resources competent in the implementation. The more precise and competent the implementation is, the higher the success rate of bureaucratic reform is. Often, political commitment exists, but the implementing element is not suitable. Therefore, the success rate of bureaucratic reforms is shrinking. "The right man, on the right place, in the right time" should be the concern in the implementation of bureaucratic reform. In addition, the competence here also means the accuracy of duties and functions of an established state institution, meaning that the more precisely established institutional organization will determine the success of the task carried out by the government. Therefore, every institution has clear duties and functions in the implementation of the bureaucracy.

\subsection{Solutions through the Bureaucratic Reform Strategy}

In fact, the solution to the obstacles and challenges in the bureaucratic reform effort may refer to the obstacles and challenges previously expressed. It is highly demanded to eliminate all the obstacles and prevent the recurrent of such thing in the bureaucracy. The political commitment of the state leadership has actually existed and this must be maintained even more strongly as this is a major prerequisite. This is a key strategy in the implementation of bureaucratic reform. This political commitment needs to be formulated in policy arrangement and what should be highlighted is the implementation and evaluation of the policy.

Another strategy to consider in the bureaucratic reform is the institution responsible for creating and guarding this bureaucratic reform policy. In some countries, the ways may vary, for example the Bureaucracy Reform Commission Administration (such as South Korea) or the Ministry of Interior. Indonesia should be grateful that in the new cabinet announced last October 2009 the institution responsible for overseeing bureaucratic reform policy or perhaps reaffirming the importance of bureaucracy reform is the Ministry of Administrative Reform and Bureaucracy Reform. This ministry must struggle harder to realize bureaucratic reform, even this organization must have great mandate since their authority is to set, cancel, overhaul, restructure and reverse the process, structure and apparatus resources in Indonesia (Prasojo, 2009). This ministry can be regarded as the main engine of bureaucratic reform in Indonesia.

The next strategy is to determine the main focus and priority in bureaucratic reform and its achievement targets (Prasojo, 2007). The focus of bureaucratic reform in Indonesia is the review of: (1) existing bureaucratic structures; (2) the analysis of governance and development processes; (3) the change of apparatus resource management; (4) the change of relationship between government and society equal; (5) changes in the supervision system; and (6) changes in financial management. It is stated that the implementation of the focus and priorities are heavily influenced by the commitment and capabilities possessed by the government and the resistance that exists in the bureaucracy. The most moderate way (soft road) that is suggested is to improve the management of the civil service reform. Related to the previous explanation, a more technical or practical level in improving the apparatus resource management is by improving the recruitment system, performance system, remuneration system and filling system of position/promotion. 
The essence of the bureaucratic reform strategy described above is as a form of solution to the obstacles and challenges previously expressed. Prioritizing a strategy on the agenda of bureaucratic reform is important and should be arranged, controlled and directed systematically, so that the implementation of bureaucratic reform is not stagnant.

\subsection{Bureaucratic Reform in Indonesia as a Demand}

The discourse on bureaucratic reform is not really a new thing, either in Indonesia or the rest of countries in the world. Bureaucratic reforms essentially lead to efforts that need to be made in the form of meaningful changes in a government bureaucratic system. The term change itself is quite diverse in its terminology; some call it reform, reformation, rationalization and many more.

In these terms, there are contained elements of similarity that is a change. When examined further, the substance and the terms have significant differences which will further lead to differences in the implementation. What is more important, however, is to provide a clear limitation of the change itself so as to provide a clear picture of the meaning or substance in question. However, in the overall context, the authors see it as a movement that is not very different in its meaning, namely the existence of a comprehensive change covering various aspects in it.

In Indonesia, government bureaucracy reform is part of the total reform demands covering political, economic, social and legal aspects. The meaning of reform accordingly is as follows: "The reform of a paternal, autocratic, mortolytic and centralistic system with a strong regimentation and the often distorted government intervention (corruption, collusion, cronyism and nepotism) towards a system and a more open, democratic, egalitarian and tolerant political culture in which the protagonist of the economy is a society in a more fair market system (Tjokrowinoto, 2001)."

Bureaucracy reform is essentially part of the reform of state administration, seen from the understanding that the bureaucracy is one of the elements of state administration that runs the functions of government in the form of public services. In this regard, the actual reform of state administration, including the reform of government bureaucracy, is not a new thing in Indonesia because it happened when the transition of power from the old order to the new order.

a) The Implementation of Bureaucracy Reform

To respond to the public's demand for the need for bureaucratic reform in Indonesia, some efforts that have been made by the government in the bureaucratic system in Indonesia cannot be ignored. Efforts that have been made include:

1) The abolition of bureaucratic mono loyalty in one particular party (formerly to Golkar);

2) The development of bureaucratic neutrality that must be cleared from the influence of political parties. Even the bureaucracy is merely allowed to choose but not to be elected (except to quit the state office) which means that the bureaucracy is not participatory as stipulated in Government Regulation No.5 of 1999 and changed with Government Regulation No.12 of 1999 on Civil Servant becoming member of political party;

3) As a consequence of these two things, every member of the bureaucracy is released without any pressure to vote at the time of the election and may decide the choice as willed.

In fact, the changes made through such efforts can be said to be less or even unaffected by the bureaucratic system in principle, especially when it is associated with changing the pattern and culture of corruption in bureaucratic work. In other word, the demand for a comprehensive bureaucratic reform is basically not yet accommodated.

b) The Success of Bureaucratic Reform

It does not seem fair enough if the efforts that the government has undertaken to implement bureaucracy reform are absent from appreciation. Based on possible objective considerations, the authors suggest that 3 (three) of the eight (8) areas of bureaucratic reform change can be said quite successful. First, the institutional sector can be regarded as an area of change that has been successfully realized, started from the Ministry of Finance which has institutional restructuring through the change, establishment and merger of its work units followed by Ministry of Administrative and Bureaucratic Reform 
which cut some echelon I and echelon II units. Similarly, the State Administration and State Personnel Agency removed several positions even to the level of echelon IV. Recently, there are 6 Ministries/Institutions proposing institutional restructuring namely National Nuclear Energy Agency, Central Bureau of Statistics, Ministry of Public Housing, Indonesian Institute of Sciences, Public Service Board and Family National Planning and Ministry of SOEs. This institutional reform is closely related to the purpose of government efficiency, one of which is by pressing the expenditure of employees/officials who occupy certain positions. With increasingly rational number of positions, the resulting performance is also in line with the burden issued by the government. In addition, effectiveness can be realized, because the fewer workflows are pursued as a consequence of the removal of certain positions within the organization. The peak of unit restructuring or removal is when the government abolished (joint or dissolved) 10 Non-Structural Institutions whose existence was considered ineffective. Another reason for the dissolution or merger of NonStructural Institutions is that its duties and functions overlap with other institutions, the institution has been inactive and some have never been established. Non-Structural Institutions which were merged or dissolved, among others, were the National Law Commission and P3D which were transferred to the Ministry of Law and Human Rights, the National Book Council (its duties and functions were transferred to the Ministry of Education and Culture), the National Aeronautics and Space Council, whose policy formulation functions were transferred to the Ministry of Research and Technology and several other Non-Structural Institutions.

c) Manifestation of Good Governance

There are 4 (four) main principles as the manifestation of good governance. They are:

1) The rule of law. Every state action must be based on law and not based on unilateral action with the power of a leader. The law must be upheld and put forward, but now politics is put forward in solving various problems.

2) Transparency. By promoting the rule of law, it will lead to the openness of the government in providing various information to the people over government programs that have been implemented for accountable to the people. This principle requires the opening of opportunities for people to submit a response and criticism to the government that seems not transparent. Good governance that is open/transparent will provide adequate information/data to the people as material to conduct the assessment of the government. Examples of transparency can be found in the management/use of the budget, recruitment of civil servants, transparency in decision making, press release through print and electronic media and call center in public services. The involvement of non-governmental organizations in some Government activities and the most popular openness right now is through the Government website.

3) Participation. The principle of public or community participation involves the active and passive involvement of the community, especially those who will be subjected to public policy in the decision-making process. Public participation is important because they are the ones affected by public policy and they should be placed as subjects in every public policy. In that context, there are two important mechanisms needed in the participation of the community, the hearing of the parties involved and the community's right to information.

4) Accountability. This principle is important, so that every decision taken by the government is based on a mature and accountable consideration to the community. One important aspect of the principle of accountability in bureaucratic reform is the discretionary authority. Police action to arrest or not a person, for example, is strongly influenced by the authority of police discretion. The use of this discretion is potential for the delivery of forms of corruption by law enforcement personnel. The use of discretion will bring benefits to society when considering the general principles of good governance that become the "spirit" of the Government Administration Act (Seminar at Mahendradata University). 


\section{Conclusions}

Bureaucracy reform is wanted by various parties, but it is quite challenging to realize. There are enough theories about bureaucracy improvement for better governance; however the implementation requires hard work and strong commitment from all related parties, not only the bureaucrats but also the people. In Indonesia, bureaucratic reform still remains a dream; although in the last 10 years, there have been efforts to improve government bureaucracy. The development of bureaucratic reform in Indonesia is not as fast as what people imagine. Not only Indonesia, but also various countries, such as China, Japan and South Korea, has shown that there is no instant result in bureaucratic reform.

The philosophy of public service is to place the people as subjects in the governance process. The morality of public service is a derivation of the philosophy, namely the empowerment of society in relation to the power structure. The ideal public service, according to the New Public Service paradigm, is that the public service must be responsive to the various interests and values. The government's task is to negotiate and elaborate various interests among citizens and community groups.

\section{References}

Soemitro, R. H. (1999). Legal Research Methodology and Yunimetry. Jakarta: Ghalia. Ibrahim, J. (2005). Theory and Methodology of the Invention of Normative Laws. Malang: Banyumedia. Marzuki, P. M. (2006). Legal Research. Jakarta: Kencana Prenada Media Group.

Ardhiwisastra, Y. B. (2000). Interpretation and Constitution of the Law. Bandung Alumni.

Suwoto. (1990). Power and Responsibility of the President of the Republic of Indonesia. Dissertation of Universitas Airlangga Surabaya.

Excerpted from the Material of the Corruption Eradication Commission (Komisi Pemberantasan Korupsi/ KPK) at the Seminar on Bureaucratic Reform at Hotel Indonesia on December 3, 2008.

Brodjonegoro, Bambang P. S. (2008). The Bold Path of Bureaucratic Reform. Jakarta: Seputar Indonesia.

Prasojo, E. (2007). Politics of Bureaucratic Reform. Kompas: Jakarta.

Tjokrowinoto, M. (2001). Bureaucracy in Polemic. Malang: Pusat Studi Kewilayahan Universitas Muhammadiyah Malang. 